\title{
Aplikasi Media Sosial sebagai Alat Politik Donald Trump (Netnografi Cuitan Trump di Twitter)
}

\author{
Yohanes Ivan Adi Kristianto ${ }^{1}$, Hanna Nurhaqiqi ${ }^{2}$ \\ 'Hubungan Internasional, Universitas Pembangunan Nasional "Veteran" Jawa Timur, Surabaya, Indonesia \\ 2Ilmu Komunikasi, Universitas Pembangunan Nasional "Veteran" Jawa Timur, Surabaya, Indonesia \\ Contact: yohanes.ivan.hubint@upnjatim.ac.id
}

\begin{abstract}
Every political actor, either at local, national, or global levels, tends to demonstrate their characteristics, including Donald John Trump. Different from his predecessors, Trump decides his communication style by using simple, easily understood, and solid words. Meanwhile, for the media, Trump tends to prioritize social media, such as Twitter, as his tool. Using the concept of CNN Effect and Agenda-Setting, this paper aims to analyze the interests of Trump in using Twitter as the communication tool and verify the concept of CNN Effect by using the case study of Trump's utilization of social media. Then, by applying agenda setting, the authors analyze the content of Trump's tweet and the interests following. A literature study is fully applied in this paper. Whereas, the time scope of this research is limited from Trump's campaign period until September 2020. This research argues that the effects of Trump's tweets in his Twitter account have similar implications with the concept of the CNN Effect. This also confirms that CNN Effect can occur not only in mass media but also in social media. Secondly, the paper argues that Trump consistently voice particular issues through his Twitter account in order to achieve his plans manifested in his campaign.
\end{abstract}

Keywords: CNN Effect, agenda setting, Trump, tweets, political manifesto

\section{ABSTRAK}

Setiap aktor politik, baik dalam tingkat lokal, nasional, ataupun global, cenderung menunjukan karakteristiknya masing-masing, salah satunya adalah Donald John Trump. Berbeda dengan pendahulunya, gaya komunikasi publik unik. Trump memilih gaya komunikasi yang ringkas, mudah dipahami masyarakat AS, dan padat. Sementara, Trump cenderung memprioritaskan media sosial sebagai alatnya, seperti Twitter. Menggunakan konsep CNN Effect dan agenda setting, makalah ini bertujuan untuk mengetahui kepentingan Trump dalam penggunaan Twitter sebagai alat komunikasi publik serta memverifikasi konsep CNN Effect menggunakan studi kasus komunikasi media massa oleh Donald Trump. Oleh karenanya, pada bagian awal, makalah mendeskripsikan efek yang ditimbulkan akibat cuitan (tweet) Trump di Twitter dengan konsep CNN Effect. Kemudian, memakai konsep agenda setting, penulis menganalisis konten cuitan Trump dan apa saja kepentingannya yang ingin ditunjukan kepada masyarakat luas. Penelitian ini menggunakan netnografi dengan mengumpulkan data crawling. Sedangkan, penelitian di fokuskan pada kampanye Trump hingga September 2020. Makalah ini berpendapat bahwa efek dari cuitan Trump pada akun Twitternya memiliki implikasi yang relatif sama dengan CNN Effect. Hal ini mengkonfirmasi pula bahwa CNN Effect bisa terjadi tidak hanya di media massa, namun juga media sosial. Pendapat kedua adalah Trump konsisten menyuarakan isu-isu tertentu melalui akun Twitternya secara konsisten supaya kepentingan Trump yang dimanifestasikan dalam kampanyenya tercapai.

Kata Kunci: CNN Effect, agenda setting, Trump, cuitan, manifesto politik

\section{Pendahuluan}

McQuail (2010) dalam bukunya yang berjudul McQuail's Mass Communication Theory menyatakan bahwa media modern mengalami evolusi terus menerus. Awalnya, media berbentuk buku, namun, lambat laun koran, radio, televisi, dan internet menjadi media dalam 
lingkup kontemporer. Internet yang menjadi media paling terbarukan melahirkan media sosial yang hingga kini sering diaplikasikan sebagai alat politik. Marquat, Ohme, dan Moller (2019) menemukan bahwa sebanyak tak kurang dari 50\% individu di dunia dengan rentang usia 18-29 tahun menggunakan media sosial pada 2010 dan seterusnya. Hal inilah yang memicu penggunaan media sosial, termasuk Twitter, sebagai media penyalur kepentingan politik.

Di Indonesia, penggunaan Twitter sebagai alat berkomunikasi bagi politisi mulai marak sejak pemilihan kepala daerah (pilkada) 2012. Hal itu dilanjutkan dengan dibuatnya akun-akun politisi nasional. Bahkan, mantan presiden Susilo Bambang Yudhoyono (SBY) dan presiden Joko Widodo (Jokowi) pun membuat akun dan mendaftarkan diri kepada Twitter supaya akun mereka diverifikasi. (Anshari, 2013) Beberapa tahun berselang sejak pilkada 2012, akun-akun politisi tidak hanya dimiliki oleh para pejabat, melainkan orang-orang yang terafiliasi dengan kepentingan dan aktor politik yang memiliki jabatan.

Dalam level internasional, tokoh-tokoh politik ternama juga memakai Twitter sebagai media komunikasi, termasuk oleh Donald John Trump, Presiden Amerika Serikat (AS) saat ini. Akun Twitter Trump (@realDonaldTrump) sudah diikuti oleh 85.8 juta orang. Banyaknya pengikut Trump mengindikasikan bahwa presiden AS ini menggunakan media sosial tersebut secara serius sebagai alat komunikasi politik.

Selanjutnya, makalah ini bertujuan untuk menganalisis kepentingan Trump dalam penggunaan Twitter serta mencari jawaban mengapa Trump menyuarakan isu di akun Twitternya secara konsisten. Hal ini penting diteliti karena adanya kecenderungan pergeseran penggunaan alat komunikasi, dari media massa ke media sosial, meskipun tidak sepenuhnya aktor politik beralih ke media sosial. Selain itu, konsistensi Trump dalam menyuarakan isu kebangkitan AS, sentimen anti Republik Rakyat Cina (RRC), dan anti imigran perlu ditelaah. Hal ini menarik dianalisis untuk melihat apakah hal itu berpengaruh pada citra Trump masa kini maupun mendatang, terutama berkaitan dengan pemilihan presiden (pilrpes) AS.

Pemilihan Twitter sebagai fokus obyek penelitian didasari dari jumlah pengikut Trump pada media sosial tersebut yang lebih banyak dibandingkan pengikutnya di Instagram, Facebook, maupun Youtube. Sementara itu, penelitian ini dibatasi dari periode kampanye Trump, yakni Januari 2016, sampai September 2020 karena pada periode tersebut Trump aktif terjun ke dalam dunia politik.

Penelitian ini berusaha menjawab pertanyaan mengapa Trump memilih media sosial sebagai alat komunikasi politik. Pertanyaan ini sekaligus memverifikasi apakah konsep CNN Effect, dimana efek penggunaan media sosial dengan studi kasus Trump menimbulkan implikasi yang identik dengan CNN Effect, perlu direvisi dengan beberapa tambahan. Tambahan yang dimaksud ialah CNN Effect tidak hanya terjadi pada media massa, namun juga media sosial. Pertanyaan penelitian kedua ialah mengapa Trump secara konsisten menyuarakan isu-isu terkait kejayaan AS, sentimen anti-RRC, dan anti-imigran.

\section{Media Massa}

Media massa adalah sarana komunikasi yang dirancang untuk menjangkau banyak orang, seperti televisi, radio, koran, majalah, dan film. Sedangkan, dalam konteks media 
terbarukan, media berupa media internet dan media sosial. (Davis, 2012)

Sementara itu , menurut Herman dan Chomsky (1988), media massa memiliki peran dalam melakukan propaganda karena adanya mobilisasi bias informasi ataupun kontrol atas berita yang dimiliki suatu media. Hal ini dapat disebut sebagai suatu 'pasar bebas' dalam negara demokrasi karena ramainya produsen informasi oleh setiap media. Informasi bergerak di antara publik dapat saling dipengaruhi oleh aktor-aktor dominan dalam pemberitaan media.

Bagi Marshall McLuhan, kritik akan kehadiran teori media massa baik untuk kelas atas, menengah maupun bawah hanya memiliki satu visi, yakni penilaian konsumen (consumer ratings). Maka, media massa memiliki kecenderungan untuk tidak pernah berada pada posisi netral atau tidak berpihak. Pemasangan iklan serta kepemilikan saham menambah potensi ketidaknetralan media massa. (Taylor \& Harris,2008)

Melalui berbagai pengertian media massa dari beberapa ahli, penulis mendefinisikan bahwa media massa adalah suatu sarana komunikasi strategis dapat mempengaruhi khalayak luas dan memiliki motivasi dalam aktivitas penyebaran pesan. Setiap pemilihan media tertentu relatif memengaruhi khalayak seperti apa yang akan dijangkau dengan jenis pesan yang berbeda pula.

\section{Media Sosial}

Media sosial memiliki makna yang lebih spesifik jika dibandingkan dengan media internet. Definisi dari media sosial adalah apapun yang menggunakan aplikasi dasar website yang mengijinkan siapapun untuk menciptakan informasi dan saling menukar konten (Saleh, 2014). Media sosial memiliki ruang yang lebih dalam interaksi antar individu serta akses yang lebih mudah dan luas.

Menurut Chang, Chu dan Welsh (2013), internet dan media sosial memiliki tiga implikasi penting bagi perkembangan masyarakat sipil, yakni: (1) menyediakan sumber informasi alternatif; (2) menurunkan biaya partisipasi politik; dan (3) meningkatkan kapasitas mobilisasi kekuatan oposisi. Maka, media sosial turut serta dalam meningkatkan literasi politik kepada publik, khususnya dalam menguatkan partisipasi politik. Hal ini sebagai bentuk kemampuan publik dalam memahami hak dan kewajiban sebagai masyarakat sipil.

Terminologi media sosial terus berubah seiring perkembangan teknologi dan praktik yang berubah -yang dahulu dikenal sebagai Web 2.0 atau 'new media' sekarang biasanya disebut sebagai media sosial atau, lebih formal, situs jejaring sosial (Boyd dan Ellison, 2008). Evolusi ini menghadirkan partisipasi, konektivitas, user-generation, penyebaran informasi ,dan kolaborasi. (Henderson \& Bowley, 2010)

Perhatian akan adanya media sosial dikaitkan dengan fenomena media baru digital seperti blog, situs social networking, layanan lokasi, microblogs, situs jejaring foto, dan video dan lainnya yang dapat disebar dan berkomunikasi dengan satu sama lain secara aktual melalui akses personal dari gawai pribadi (Bechmann \& Lomborg, 2013)

Dalam perkembangannya, pengaruh media sosial cukup signifikan dalam mengubah opini di masyarakat. Berawal pada penggunaan televisi kabel oleh Clinton, saluran televisi Fox News oleh Bush, Youtube dan Buzzfeed oleh Obama, dan Trump dengan twitter, penggunaan 
media sosial dalam dunia politik semakin populer (Farnsworth. 2018). Twitter, dengan identitas 140 karakter, memiliki budaya opini yang berbeda dibandingkan dengan media sosial lainnya. Rentan dengan satire dari ironi hingga sarkasme, twitter memiliki ruang dalam membentuk opini yang keras dan kuat (Hannan, 2018).

Melalui definisi-definisi tersebut, kesimpulannya ialah media sosial merupakan sarana yang dinamis, menggunakan internet, dan memberikan kesertaan aktif kepada dua pihak, yakni komunikan (publik) dan komunikator (pemilik akun). Melalui cuitan akun Twitternya, publik dapat melihat warganet yang merespon kicauan Trump, termasuk lawan politiknya. Gaya komunikasi Trump yang khas mempermudah publik untuk mengidentifikasi lawan serta substansi dari cuitan Trump. (Farnsworth, 2018).

\section{CNN Effect}

CNN Effect merupakan sebuah konsep interdisipliner yang diterjemahkan berbedabeda oleh beragam ahli. Gilboa (2005) melalui penelitiannya yang berjudul the CNN Effect: The Search for a Communication Theory of International Relations menyatakan bahwa meskipun konsep ini memakai kata "CNN", hal ini bukan berarti CNN menjadi subyek utama konsep. CNN Effect menetapkan subyek yang dimaksud ialah segala media massa yang memiliki cakupan global serta terbiasa menyiarkan berita aktual seperti breaking news atau laporan khusus yang menyela acara atau berita terjadwal.

Robinson (1999) menggarishbawahi bahwa CNN Effect merupakan suatu keadaan dimana berita (news) dapat memengaruhi atau menentukan langkah pemangku kebijakan. Sementara, Seib (2002) menjelaskan bahwa berita utama (headline news) dan breaking news yang disiarkan secara terus-menerus dapat menekan proses pembuatan kebijakan. Livingston dan Eachus (1997) memiliki subyek yang berbeda dalam memapaparkan konsep CNN Effect. Mereka menyatakan bahwa pembuat kebijakan dari tingkat elite berpotensi kehilangan kontrol atas pendiriannya terhadap sebuah kebijakan yang telah direncanakan atau disahkan akibat berita di media massa. Selanjutnya, Neuman (1996) turut menambahkan bahwa berita di media massa membuat pembuat kebijakan tidak punya pilihan. Krisis yang disebabkan pemberitaan di media massa memengaruhi emosi publik sehingga publik mendesak pembuat kebijakan untuk menerapkan kebijakan anti krisis.

Freedman (2000) dalam Victims and Victors: Reflections on the Kosovo War membedakan CNN Effect dengan Bodybags Effects dan Bullying Effects yang memiliki kemiripan dengannya. Dia menekankan bahwa CCN Effects diwujudkan melalui penggambaran penderitaan subyek tertuju dengan tujuan untuk memaksa pemerintah mengintervensi keadaaan. Sedangkan, Bodybags Effects adalah usaha untuk menggambarkan penderitaan militer negara pengirim misi humaniter dengan maksud untuk memengaruhi pembuat kebijakan agar menarik pasukan. Sementara itu, Bullying Effects merupakan usaha pembingkaian (framing) penggunaan kekuatan militer berlebihan sehingga militer ditarik akibat desakan publik.

Terakhir, Strobel (1997) berargumen bahwa tidak ada bukti spesifik yang menyatakan media massa mampu memengaruhi suatu kebijakan. Namun, Strobel setuju bahwa berita di 
media massa berperan dalam proses pembuatan kebijakan.

Dari penemuan yang disampaikan berbagai sumber, penelitian ini menarik garis merah bahwa konsep CNN Effect adalah penyiaran berita yang disiarkan oleh media massa dengan tujuan untuk setidaknya memengaruhi proses pembuatan kebijakan atau pengubahan arah kebijakan. Definisi ini, kemudian, dijadikan sebagai alat analisis pada bagian selanjutnya.

\section{Agenda Setting}

Agenda setting adalah suatu konsep yang cukup sering didiskusikan pada bidang ilmu komunikasi, politik, dan hubungan internasional. Banyaknya diskusi tersebut melahirkan variasi definisi agenda setting.

Kurniasari (2005) melihat agenda setting sebagai kapabilitas media yang rutin menyiarkan berita atau informasi dengan tujuan untuk mengangkat suatu isu biasa menjadi isu yang perlu dibahas. Dalam pemaparannya, Kurniasari belum menjelaskan media apa yang dimaksud.

Kur Lang dan G.E. Lang (1959) mengungkapkan bahwa agenda setting adalah fenomena dimana media massa membingkai suatu permasalah secara kontinu dengan harapan publik tersugesti dengan pesan yang ingin disampaikan. Dengan tersugesti, publik diarahkan untuk berempati terhadap masalah yang dibingkai.

McCombs dan Shaw (1972) mengatakan bahwa agenda setting memiliki tiga tahapan sebelum informasi yang telah dibingkai dipublikasi ke masyarakat umum. Pertama, media massa mencoba untuk merangkum semua informasi atau berita yang telah dikumpulkan. Kedua, rangkuman berita tersebut diseleksi oleh divisi khusus dari lembaga media massa. Ketiga, bagian khusus tersebut memasang skala prioritas. McCombs dan Shaw juga menambahkan bahwa kadangkala isu yang dilempar ke publik tidak hanya berupa berita, namun juga isu tersebut sudah ditambahkan perspektif media yang mempublikasi. Meski agenda setting fokus untuk menaikkan isu tertentu, Ritonga (2018) mengkritisi bahwa agendasetting tidak selalu berjalan efektif karena ada faktor sosial ekonomi yang kurang mendukung. Contohnya, masyarakat di lingkungan ekonomi kebawah yang tidak mampu mengakses sumber informasi relatif tidak terpengaruh dengan framing media massa. Framing atau pembingkaian adalah usaha untuk mengkonstruksi suatu fenomena yang sesuai dengan cara pandang pembingkai.

Selain Kurniasari, konsep di atas yang dipaparkan berkaitan dengan media massa. Kemudian, apakah media sosial tidak dapat digunakan untuk agenda setting? Apakah media setting hanya berlaku di media massa?

Feezell (2017) menyanggah anggapan bahwa konsep agenda setting berlaku eksklusif untuk media massa. Dia berargumen bahwa media sosial juga bisa berisi agenda setting dari pihak-pihak yang berkepentingan. Menurutnya, ada tiga keunggulan dari media sosial dibanding media massa. Pertama, opini politik dari opinion leaders yang tersebar lebih real time. Opinion leaders yang dimaksud ialah entitas yang memimpin munculnya sebuah tren. Kedua, media sosial lebih efisien. Ketiga, media sosial relatif lebih mudah menjangkau berbagai pihak, termasuk pihak yang kurang tertarik politik. Terakhir, media sosial juga efektif untuk penyampaian pesan karena faktor jaringan dan algoritma. 
Menurut Khusnia, et al (2018), berpendapat bahwa para politisi sangat berkepentingan dalam pembentukan citra politik dirinya melalui komunikasi politik. Baik komunikasi yang disampaikan melalui verbal maupun non verbal dapat memberikan makna mengenai isu tertentu atau kepentingan yang ingin diutarakan.

Singkat kata, media massa dan entitas dalam media sosial mempunyai kapabilitas untuk membingkai suatu fenomena menjadi suatu isu yang sering diperbicangkan publik. Tujuan agenda setting ialah untuk memengaruhi opini publik terhadap fenomena tertentu. Meskipun begitu, agenda setting tidak selalu berhasil.

\section{Metode}

Penelitian ini menggunakan metode netnografi dengan memanfaatkan data social network analysis sederhana melalui aplikasi Unionmetrics. Data yang diambil melalui Twitter Snapshot Report dengan menampilkan potential impressions dan contributor pada cuitan Trump dengan memanfaatkan data kualitatif dan kuantitatif. Data yang diperoleh melalui Unionmetrics ini dilakukan dengan data crawling akun @realDonaldTrump dengan tiga pencarian kata kunci : make america great again, migrant, dan china. Data kuantitatif yang disajikan merupakan data yang telah diolah oleh penelitian yang telah dipublikasi.

Ada tiga komponen inti dalam bab "Pembahasan dan Hasil". Pertama, penulis memaparkan Twitter sebagai sebuah media sosial serta media internasional seperti CNN dan $B B C$ World sebagai media massa. Kedua, penelitan ini menampilkan beberapa cuitan Trump di Twitter sebagai sampel dan siapa saja figur terkenal yang menanggapi cuitan tersebut. Hal ini dilakukan untuk menunjukan apakah cuitan Trump mampu memengaruhi publik. Pada poin ini pula, peneliti membandingkan temuan tersebut dengan konsep CNN Effect. Perbandingan ini perlu untuk menunjukan apakah konsep CNN Effect hanya berlaku untuk media massa atau tidak.

Ketiga, penelitian ini menggunakan agenda setting sebagai alat analisis untuk mengetahui apakah cuitan Trump yang konsisten mengangkat isu tertentu memuat kepentingan tertentu. Pada bagian ini, penulis mencantumkan beberapa cuitan Trump yang konsisten mengangkat isu kejayaan AS, anti-RRC, dan anti-imigran.

Terakhir, kebaruan penelitian ini terletak pada belum adanya penelitian sebelumnya yang menghubungkan antara gaya komunikasi Trump yang frontal dan penggunaan Twitter olehnya. Selain itu, penelitian ini menginisiasi analisis kemiripan konten akun Twitter Trump.

\section{Hasil dan Pembahasan}

Sebelum menganalisis pertanyaan penelitian lebih mendalam, penulis menegaskan bahwa institusi berita dengan cakupan global seperti $C N N, B B C$, Al Jazeera, dan lainnya merupakan media massa. Al-hindawi dan Ali (2018) menilai bahwa entitas seperti ketiganya memiliki kekuatan untuk memengaruhi massa dalam jumlah banyak menggunakan fasilitas penyiaran dan internet. 
Sementara itu, Twitter merupakan salah satu perwujudan media sosial. Hal ini disebabkan adanya fitur menanggapi ide seseorang dengan cara reply, retweet, dan like. Meskipun media sosial merupakan terminologi baru, perdebatan apakah media sosial termasuk media massa dapat dilaksanakan. Sebabnya, media sosial juga dapat memengaruhi massa dalam jumlah banyak. Selain itu, sebagian media massa umumnya juga menggunakan media sosial untuk keperluan pemasaran.

\begin{tabular}{|c|l|r|r|r|l|}
\hline Isu & \multicolumn{1}{|c|}{ Tanggal } & Balasan & Retweet & Disukai & Respon Terpopuler (Jumlah Pengikut) \\
\hline \multirow{5}{*}{ Anti imigran } & 22 April 2020 & 15.8 & 33.7 & 164.1 & @ FrankDAngelo (184.7) \\
\cline { 2 - 7 } & 20 April 2020 & 70.3 & 85.5 & 386.9 & @ DavidMicRot (72.8) \\
\cline { 2 - 7 } & 13 September 2019 & 8.5 & 16.3 & 68.9 & @ lesleyabravanel (61.1) \\
\cline { 2 - 7 } & 28 Desember 2018 & 50.6 & 30 & 138.4 & @ JeffreyGuterman (346.4) \\
\cline { 2 - 7 } & 05 Nopember 2016 & 1.9 & 14 & 21.6 & @ MollyJongFast (707.5) \\
\cline { 2 - 7 } & 29 Mei 2020 & 29.5 & 41.2 & 137.8 & @ digiphile (238) \\
\cline { 2 - 6 } Anti RRC & 12 Mei 2020 & 32.1 & 44.1 & 184 & @ DeanObeidallah (110.4) \\
\cline { 2 - 6 } & 17 Nopember 2019 & 33.8 & 22.5 & 94.8 & @ mskristinawong (28.4) \\
\cline { 2 - 6 } & 5 Desember 2018 & 14 & 12.4 & 62.1 & @ williamlegate (140.5) \\
\cline { 2 - 6 } & 17 Desember 2016 & 17 & 20 & 50.2 & @ JeffreyGuterman (346.4) \\
\cline { 2 - 6 } & 21 Agustus 2020 & 16.9 & 23.2 & 83.7 & @ JesseDamiani (20.3) \\
\cline { 2 - 6 } & 4 Maret 2020 & 16.9 & 35.8 & 187.4 & @ jeremynewberger (74.4) \\
\cline { 2 - 6 } & 14 September 2019 & 23.3 & 40.5 & 215 & @ davidmweissman (202.3) \\
\cline { 2 - 6 } & 07 September 2018 & 13.1 & 15 & 57.8 & @ jeffstrater (12.1) \\
\cline { 2 - 6 } Kejayaan AS & 9 Desember 2017 & 28 & 17.9 & 56.9 & @ mattmfm (84.6) \\
\cline { 2 - 6 } & & & &
\end{tabular}

Tabel 1. Cuitan Trump beserta jumlah balasan, retweet, disukai (likes), dan respon dari akun terverifkasi. (Sumber: diolah sendiri dari akun Twitter @realDonaldTrump)

Tabel 1 memperlihatkan sampel cuitan Trump dengan jumlah lima belas cuitan. Setiap isu (isu anti imigran, anti RRC, dan kejayaan AS) diambil tiga sampel yang berasal dari cuitan tahun 2016-2020. Jumlah balasan (replies), retweet, disukai (likes), dan jumlah pengikut (followers) ditampilkan dalam satuan ribuan. Sebagai contoh, angka 15.8 balasan berarti terdapat 158.000 balasan. Kolom kelima, kolom respon terpopuler, diisi oleh akun terverifikasi (verified accounts) yang menanggapi cuitan Trump. Akun terverifikasi seringkali dimiliki oleh figur ternama yang mempunyai jumlah pengikut lebih banyak daripada akun biasa.

Berdasarkan Tabel 1, cuitan Trump terkait ketiga isu relatif ditanggapi oleh puluhan warganet. Disamping itu, akun terverifikasi yang merespon pun diikuti oleh puluhan ribu followers. Tanggapan dari akun terverifikasi juga akan dilihat oleh pengikut dari akun-akun tersebut. Hal ini mengindikasikan bahwa ide-ide yang dicuitkan Trump tersampaikan kepada tak kurang dari puluhan ribu pengguna Twitter.

Apa yang dicuitkan Trump pun cenderung langsung direspon oleh penerima pesan. Sementara itu, cuitan Trump dari 2016 hingga 2020 berjumlah tak kurang dari 23 ribu cuitan. Garis besarnya, Trump relatif mengandalkan media sosial sebagai corong kebijakannya. Ditambah, pesan yang dikirimkan Trump tersampaikan oleh banyak khalayak secara cepat dan memengaruhi mereka, baik itu setuju atau menolak pendapat Trump. Meskipun ada bantahan dari publik, hal ini tidak berarti Trump gagal memengaruhi opini mereka. Justru, dengan ditanggapi, ide yang ingin disampaikan Trump semakin dibicarakan atau menjadi salient issues. 
Fenomena yang muncul akibat cara Trump berkomunikasi memiliki kecenderungan kesamaan dengan CNN Effect. Perbedaannya ialah akun Trump merupakan media sosial, sedangkan konsep CNN Effect fokus pada media massa. Namun, kembali ke definisinya, media sosial merupakan bagian dari media massa, sehingga, fenomena yang ditunjukan oleh akun Twitter Trump dapat dikategorikan sebagai salah satu bentuk CNN Effect. Pendapat ini diperkuat dengan ditanggapinya cuitan Trump oleh beberapa media massa ternama, seperti CNN, ABC News, NY Times, BBC, dan Reuters. Alternatif lainnya, konsep CNN Effect perlu diperbarui mengingat jalan pikir konsep ini berpotensi terjadi tidak hanya di media massa, melainkan secara spesifik juga terjadi di media sosial.

\begin{tabular}{|l|r|r|}
\hline \multicolumn{1}{|c|}{ Isu } & Jumlah Cuitan & Persentase \\
\hline Kejayaan Amerika Serikat (Make America Great Again) & 367 & $1.53 \%$ \\
\hline Anti Republik Rakyat Cina & 560 & $2.34 \%$ \\
\hline Anti Imigran & 253 & $1.06 \%$ \\
\hline
\end{tabular}

Tabel 2. Jumlah Cuitan Trump terkait Isu Tertentu (Sumber: diolah sendiri dari http://www.trumptwitterarchive.com/archive)

Tabel 2 menjelaskan tentang jumlah cuitan Trump di akun Twitternya terkait isu kejayaan AS, sentimen anti RRC, dan sentimen anti imigran dengan rentang waktu 1 Januari 2016 hingga 19 September 2020. Menggunakan data dari situs bernama Trump Twitter Archive, penulis menemukan bahwa Trump telah mencuit sebanyak 23.945 cuitan. Menggunakan kata kunci make America Great Again, penulis menemukan sebanyak 367 cuitan yang berkaitan dengan kata kunci. Sementara, menggunakan kata China yang merujuk pada sentimen anti RRC, ada 560 cuitan yang ditulis Presiden AS tersebut. Sedangkan, memakai kata kunci migrant yang merujuk pada sentimen anti imigran, Trump telah mencuitnya sebanyak 253 cuitan.

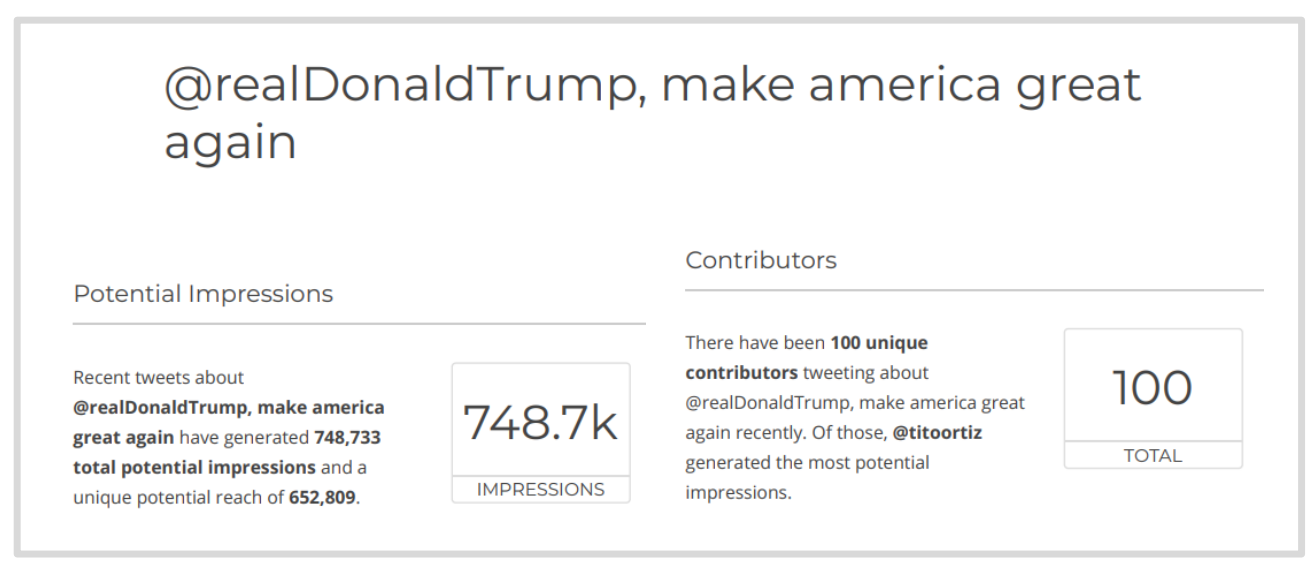

Tabel 3. Twitter Snapshot Report dengan keyword 'make america great again' (Sumber: diolah sendiri dari http://www.app.unionmetric.com)

Berdasarkan Tabel 3, akun @realDonaldTrump dengan kata kunci Make America Great Again mendapatkan jumlah impressions sebesar 748.700. Terdapat 100 kontributor teratas yang berperan dalam menyebar luaskan isu Make America Great Again, tiga peringkat pertama yakni akun@titoortiz, @Bcharlotedan @Stand4Liberty. Ketiga akun tersebut menyatakan dukungan kepada periode pemenangan Trump. Seperti @titoortiz dengan \#Trump2020, ia juga 
mencalonkan diri sebagai kandidat Huntington Beach City Council untuk Partai Republik. Kemudian @Bcharlotte dan @Stand4Liberty menggunakan hashtag \#KAG2020LandslideVictory dan \#MAGA. Kesimpulannya bahwa menjadi wajar jika yang turut me-retweet ialah mereka yang mendukung pencalonan Trump untuk presiden 2020 bahkan salah satunya ialah kandidat untuk Huntington Beach, salah satu kota di tepi pantai California Selatan.

\section{@realDonaldTrump, china}

Potential Impressions

Recent tweets about

@realDonaldTrump, china have

generated 111,311 total potential

impressions and a unique potential

reach of 92,044 .

\section{$111.3 \mathrm{k}$}

IMPRESSIONS
Contributors

There have been 91 unique contributors tweeting about

@realDonaldTrump, china recently. Of

those, @IsraelNewsLinks generated the

most potential impressions.
91

TOT AL

Tabel 4. Twitter Snapshot Report dengan keyword 'china' (Sumber: diolah sendiri dari http://www.app.unionmetric.com)

Pada Tabel 4, menunjukkan potensi impresi sebesar 111.300 dengan kata kunci china. Akun yang memberikan impresi paling besar ialah @IsraelNewsLinks, tidak terlihat nama asli serta status kesipilannya. Status profil twitter yang muncul ialah Christian, lover of Israel, patriotic American, nature lover in aw God's handiwork. Akun selanjutnya dengan impresi tertinggi ialah @mluther24 dengan \#MAGA pada status profilnya. Kemudian akun @JrAxelroad, melalui status profilnya terlihat tinggal di Brasil namun secara aktif memantau berita amerika mengenai Trump dengan retweet cuitan Trump.

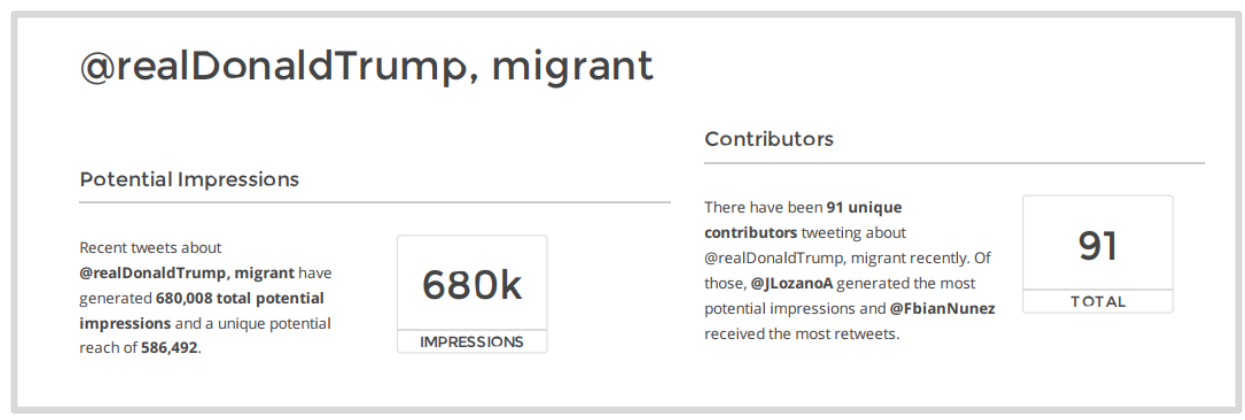

Tabel 5. Twitter Snapshot Report dengan keyword 'migrant' (Sumber: diolah sendiri dari http://www.app.unionmetric.com)

Pada Tabel 5, menunjukkan terdapat potensi impresi sebesar 680.000 dengan kata kunci migrant. Terdapat tiga akun twitter dengan impresi tertinggi yakni, @JlozanoA yakni seorang Senat Republik di Kota Puebla, Mexico, @EmpathyNow dan @educatedadult1 dengan status profilnya \#Liberal \#Democrat. Berbeda dengan dua data sebelumnya untuk kata kunci 'make america great again' dan 'china', ketiga akun dengan impresi tertinggi ini menunjukkan 
dukungannya terhadap oposisi Trump, yakni Joe Biden. Terlihat dari cuitan-cuitan yang memberikan dukungannya kepada oposisi.

Dari data yang dipaparkan di atas, terlepas dari bahasa yang digunakan, Trump memang mengangkat isu-isu spesifik, diantaranya isu kejayaan AS, sentimen terhadap RRC, dan sentimen anti-imigran. Selain itu, Trump juga menyuarakan pendapatnya berulangkali. Pertanyaan selanjutnya ialah mengapa Donald Trump menyuarakan ide-ide spesifik melalui cuitan berulangkali, namun persentase cuitannya tidak mendominasi dari keseluruhan cuitan?

Sifat cuitan akun Twitter Trump yang repetitif mempunyai kecenderungan untuk memengaruhi publik di AS. Menggunakan perspektif bisnis, produk komersial yang disuguhkan kepada publik melalui media secara repetitif berpotensi meningkatkan jumlah penjualan produk. Hal ini disebabkan karena gambaran (image) produk tertanam pada pikiran calon pembeli. Namun, penjual produk perlu memperhatikan two concept theory. Teori ini menyatakan bahwa ada saatnya suatu produk berhasil ditingkatkan pamornya melalui iklan yang dilakukan secara terus menerus (fase pertama). Tetapi, pada titik tertentu, pamor produk dapat turus akibat penayangan iklan yang repetitif (fase kedua). Fase kedua terjadi disebabkan oleh rasa bosan yang muncul dari penerima informasi iklan. (Magloff, 2019)

Apa yang dipaparkan oleh Magloff sama halnya dengan argumen Cacioppo dan Petty (1989). Menggunakan kacamata ilmu psikologi, persuasi yang disuguhkan secara terus menerus berpotensi memperkuat nilai persuasif atau justru memperlemah. Cacioppo dan Petty menggambarkan bahwa persuasi yang dilakukan pada taraf "moderat"lah yang akan memperkuat persuasi. Meskipun begitu, baik Magloff serta Cacioppo dan Petty belum secara eksplisit batas titik jenuh atau taraf "moderat".

Menggunakan pola pikir ini, cuitan Trump yang dilakukan berulangkali mengindikasikan bahwa Presiden AS ini berusaha menanamkan pemikiran tertentu. Trump sengaja menginformasikan publik bahwa isu kejayaan AS, anti RRC, maupun anti imigran adalah permasalahan yang seharusnya menjadi atensi publik.

Strategi brilian Trump juga tercermin dari jumlah cuitan yang mengandung ketiga isu tersebut. Persentase jumlah cuitan yang berkaitan dengan ketiga isu tersebut tidak melebihi dua persen. Hal ini menandakan bahwa Trump berusaha supaya ketiga isu tersebut tidak menjadi isu yang menjemukan bagi publik, sehingga ketiganya secara konsisten menjadi permasalahan yang diperbincangkan.

Pertanyaan selanjutnya ialah mengapa Donald Trump sengaja menggiring opini publik untuk memperhatikan ketiga isu tersebut. Bila dilihat dari manifesto politiknya saat kampanye pemilihan presiden AS 2016, penggiringan opini oleh Trump merupakan upaya agenda setting. Agenda setting tersebut diaplikasikan supaya publik memahami bahwa Trump sedang menepati janji kampanyenya. 
Sebelum pemilihan presiden 2016, Trump mengumumkan 17 janji kampanyenya dimana 4 diantaranya berkaitan dengan sentimen anti-Cina dan anti-imigran. Pertama, Trump berjanji untuk mengurangi defisit perdagangan dengan Cina yang menguasai pasar domestik AS. Kedua, perbatasan antara AS dan Meksiko akan dibangun tembok besar untuk mengurangi arus imigran dari selatan AS. Ketiga, RRC disebut oleh Trump sebagai manipulator mata uang, sehingga Trump menjanjikan proteksi terhadap komoditas dari negara tersebut. Terakhir, Trump menjanjikan deportasi kepada imigran tak berdokumen resmi dengan tujuan mengurangi kompetisi pasar tenaga kerja. (BBC, 2020) Sementara, semua janji kampanye Trump tersebut dibungkus dengan slogan Make America Great Again agar publik AS percaya bahwa Trump akan mengembalikan kedigdayaan AS terhadap dunia.

Singkatnya, Trump menerapkan strategi dengan cara mengeluarkan cuitan terkait kejayaan AS, sentimen anti-RRC, serta sentimen anti-imigran untuk menanamkan pemikiran kepada publik AS bahwa ketiga isu tersebut sangat penting. Dengan dianggap penting oleh publik, Trump berharap dukungan terhadap program kampanyenya tetap stabil atau meningkat, sehingga Trump dapat melanjutkan periode kedua sebagai presiden AS.

Namun, agenda setting yang dijalankan oleh Trump cenderung belum berhasil. Jajak pendapat yang dilakukan $A B C$ News memperlihatkan bahwa mayoritas publik AS melihat kebijakan imigrasi Trump terlalu keras. Mereka juga berpendapat bahwa program DACA yang disahkan oleh Barack Obama tetap diperlukan. ${ }^{1}$ Mayoritas responden berpandangan pula bahwa rencana pembangunan tembok raksasa di perbatasan AS-Meksiko perlu dibatalkan. (De Jong, 2017) Sementara itu, Rapoza (2019) melihat bahwa kesengajaan Trump untuk mendiskreditkan RRC melalui propaganda perang dagang dan sentimen anti-RRC justru berpotensi mengurangi dukungan dari partai pendukung Trump, Partai Republik. Secara tidak langsung, kurang populernya kebijakan Trump berpotensi berpengaruh pada slogan andalannya yakni Make America Great Again. Hal ini diperkuat dengan survei elektabilitas yang menunjukan bahwa kandidat Demokrat, Joe Biden, justru lebih diunggulkan. Bahkan, popularitas di kantong suara Trump menurun perlahan (Warren, 2020).

\section{Simpulan}

Penggunaan Twitter oleh Donald Trump bertujuan supaya ide yang disampaikannya tersampaikan kepada banyak orang secara cepat. Hasil dari pengaplikasian tersebut sekaligus menguji konsep CNN Effect. Konsistensi Trump dalam mengangkat isu anti-imigran, anti-RRC, dan kejayaan AS memiliki maksud yakni kepentingan Trump dalam merealisasikan janji kampanyenya. Penulis merekomendasikan kepada peneliti selanjutnya untuk menguji konsep

\footnotetext{
${ }^{1}$ DACA atau Deferred Action for Childhood Arrivals adalah program perlindungan bagi imigran tak berdokumen yang berusia dibawah 16 tahun. Program ini diusulkan dan disahkan pada masa kepemimpinan Barack Obama.
} 
CNN Effect menggunakan metode lainnya. Rekomendasi lainnya adalah penelitian lanjutan terkait strategi agenda setting Trump melalui media massa dan efek pasca pemilihan presiden AS 2020.

\section{Daftar Pustaka}

Al-hindawi, F.H. \& Ali, A.H. (2018). A Pragmatic Study of CNN and BBC News Headlines Covering the Syrian Conflict. Advances in Language and Literature Studies, 9 (3), 43-51.

Anshari, F. (2013). Komunikasi Politik di Era Media Sosial. Jurnal Komunikasi, 8 (1), 91-102.

BBC. (2020, 28 Agustus). Trump's Campaign Promises - Has He Delivered on Them? Diakses dari: https://www.bbc.com/news/world-us-canada-37982000.

Bechmann, A. \& Lomborg. (2013). Mapping Actor Roles in Social Media: Different Perspectives on Value Creation in Theories of User Participation. New Media \& Society, 15 (5), 765-781.

Boyd, D \& Ellison, N.B. (2008). Social Network Site: Definition, History, and Scholarship. Journal of Computer Mediated Communication, 13 (1), 210-230.

Cacioppo, J.T., \& Petty, R.E. (1989). Effects on Message Repetition on Argument Processing, Recall, and Persuasion. Basic and Applied Social Psychology, 10 (1), 3-12.

Chang, A., Chu, Y \& Welsh, B. (2013). Southeast Asia: Source of Regime Support. Journal of Democracy, 24 (1), 150-164.

Davis, A. M. (2012). Using the Mass Media to Promote Health. InnovAiT, 5 (12), 767-773.

De Jong, A. (2017, 25 September). Americans Back DACA by a Huge Margin (POLL). Diakses dari: https://abcnews.go.com/Politics/americans-back-daca-huge-margin-poll/story?id=50032985.

Farnsworth, S. (2018). Presidential Communication and Character: White House News Management from Clinton and Cable to Twitter and Trump. New York: Routledge.

Feezell, J.T. (2017). Agenda Setting through Social Media: The Importance of Incidental News Exposure and Social Filtering in the Digital Era. Political Research Quartely, 1-13.

Freedman, L. (2000). Victims and Victors: Reflections on the Kosovo War. Review of International Studies, 26, 335358.

Gilboa, E. (2005). The CNN Effect: The Search for a Communication Theory of International Relations. Political Communication, 2, 27-44.

Hannan, J. (2018). Trolling Ourselves to Death? Social Media and Post-Truth Politics. European Journal of Communication, 33 (2), 214-226.

Henderson, A \& Bowley, R. (2010). Authentic Dialogue? The Role of "Friendship" in a Social Media Recruitment Campaign. Journal of Communication Management, 14(3), 237-257.

Herman, E.S. \& Chomsky, N. (1988). The Political Economy of the Mass Media. New York: Pantheon Books.

Khusnia, Hartin Nur; Muhlis dan Tenri Waru. (2018). Studi Komunikasi Politik Legislator Perempuan di DPRD Provinsi NTB. Journal of Media and Communication Science, 1(2). Universitas Mataram.

Kurniasari, N.D. (2015). Agenda Setting Function (Studi Kasus Krisis Ekonomi Amerika dan Global). Jurnal Komunikasi, 9 (1), 95-104.

Lang, K. \& Lang, G.E. (1959). The Mass Media and Voting. Dalam: Budrick, E. \& Brodback, A.J (Eds.), American Voting Behavior (hal. 217-235). Glencoe: The Free Press.

Livingston, S., \& Eachus, T. (1995). Humanitarian crises and U.S. foreign policy: Somalia and the CNN effect reconsidered. Political Communication, 12, 413-429.

Magloff, L. (2019, 1 Februari). Reptition as an Advertisement Technique. Diakses dari: https://smallbusiness.chron.com/repetition-advertisement-technique-24437.html.

Marquat, F., Ohme, J., Moller, J. (2019). Following Politicians on Social Media: Effects for Political Information, Peer Communication, and Youth Engagement. Media and Communication, 8 (2), 197-207.

McQuail, D. (2010). McQuail's Mass Communication Theory. London: Sage Publications.

Neuman, J. (1996). Lights, Camera, War: Is Media Technology Driving International Politics? New York: St. Martin's Press.

Rapoza, K. (2019, 14 Mei). In Trade War, China Carpet Bombs Trump Supporters. Diakses dari: https://www.forbes.com/sites/kenrapoza/2019/05/14/in-trade-war-china-carpet-bombs-trumpsupporters/\#2c2f379650e3.

Ritonga, E.Y. (2018) Teori Agenda Setting dalam Ilmu Komunikasi. SIMBOLIKA, 4 (1), 32-41. 
Robinson, P. (1999). The CNN Effect: Can the News Media Drive Foreign Policy?. Review of International Studies, 25, 301-309.

Taylor, Paul A. \& Jan LI. Harris. (2008). Critical Theories of Mass Media: Then and Now. England: McGrawHill Open University Press.

Saleh, M. (2014). Social Media in Everyday Practice. InnovAiT, 7(10), 624-628.

Strobel, W. (1997). Late-breaking Foreign Policy: The News Media's Influence on Peace Operations. Washington, DC: United States Institute of Peace Press.

Warren, K. (2020, 1 Juli). Trump Leads Biden by 7\% in SLU/YouGov Poll. Diakses dari: https://www.slu.edu/research/research-institute/big-ideas/slu-poll/june-2020-poll/trump-biden.php. 